Vol 1. No 2. Oktober Tahun 2021 e-ISSN : 2798-5466 P-ISSN : 2798-5725

\title{
EFIKASI DIRI TERHADAP KEMAMPUAN MENULIS SKRIPSI PADA MAHASISWA BIMBINGAN KONSELING ISLAM INSTITUT ABDULLAH SAID BATAM
}

\author{
NADYA ASMARANI \\ Institut Agama Islam Abdullah Said Batam \\ Email : nadyaasmarani1@gmail.com
}

\begin{abstract}
Thesis is a scientific essay that must be written by students as part of the final requirements of their academic education. Thesis is one of the problems that are usually faced by students. Two supporting factors in completing the thesis are internal and external factors. This study was aimed to determine the influence of internal factors, namely student self-efficacy on the ability to complete their thesis. Self-efficacy is an individual's belief in estimating his ability to carry out a task to achieve certain results (Rustika, 2016). This research is a case study on students of the Islamic Counseling Guidance Study Program - Abdullah Said Institute Batam in the 7th semester of 2021. Using a quantitative approach to Pearson product moment correlation using the topics of IBM SPSS Statistics Version 20. There is a strong correlation between selfefficacy. and the ability to complete the thesis with a correlation coefficient of -0.834 . In this study, there is a strong influence between students' self-efficacy on the ability to write a thesis.
\end{abstract} Keywords: self-efficacy, writing ability, scientific essay

\begin{abstract}
ABSTRAK
Skripsi merupakan karangan ilmiah yang wajib ditulis oleh mahasiswa sebagai bagian dari persyaratan akhir pendidikan akademisnya. Skripsi menjadi salah satu permasalahan yang biasanya dihadapi mahasiswa Dua faktor pendukung dalam penyelesaian skripsi adalah faktor intern dan ekstern. Penelitian ini ditujukan untuk mengetahui adanya pengaruh faktor intern yaitu efikasi diri mahasiswa terhadap kemampuan dalam menyelesaikan skripsinya. Efikasi diri adalah keyakinan individu dalam memperkirakan kemampuannya dalam melaksanakan suatu tugas untuk mencapai hasil tertentu (Rustika, 2016). Penelitian ini merupakan studi kasus pada mahasiswa Program Studi Bimbingan Konseling Islam - Institut Abdullah Said Batam pada semester 7 tahun 2021. Menggunakan pendekatan kuantitatif korelasi Pearson product moment dengan menggunakan topik-topik IBM SPSS Statistics Versi 20. Didapatkan hasil korelasi korelasi yang kuat antara efikasi diri dan kemampuan menyelesaikan skripsi dengan nilai koefisien korelasi sebesar -0,834. Dalam penelitian ini terdapat pengaruh yang kuat antara efikasi diri mahasiswa terhadap kemampuan menulis skripsi.
\end{abstract}

Kata Kunci : efikasi diri, kemampuan menulis , karangan ilmiah

\section{PENDAHULUAN}

Menulis merupakan hal mutlak bagi insan akademisi. Budaya berliterasi di Indonesia mulai banyak dimunculkan melalui berbagai media. Literasi yang baik merupakan salah satu hal mendasar yang harus dimiliki oleh mahasiswa. National Institute for Literacy, mendefinisikan literasi sebagai kemampuan individu untuk membaca, menulis, berbicara, menghitung dan memecahkan masalah pada tingkat keahlian yang diperlukan dalam pekerjaan, keluarga dan masyarakat. Definisi ini memaknai literasi dari perspektif yang lebih kontekstual. Dari definisi ini terkandung makna bahwa definisi literasi tergantung pada keterampilan yang dibutuhkan dalam lingkungan tertentu.

Salah satu kemampuan berliterasi bagi mahasiswa adalah dalam penyelesaian tugas akhir berupa skripsi. Skripsi menurut Kamus Besar Bahasa Indonesia versi online adalah karangan ilmiah yang wajib ditulis oleh mahasiswa sebagai bagian dari persyaratan akhir pendidikan akademisnya. 


\section{STRATEGY : Jurnal Inovasi Strategi dan Model Pembelajaran Vol 1. No 2. Oktober Tahun 2021 e-ISSN : 2798-5466 P-ISSN : 2798-5725}

Skripsi menjadi salah satu permasalahan yang biasanya dihadapi mahasiswa. Dalam proses penulisan skripsi mahasiswa menemui hambatan atau kesulitan, diantaranya mencari literatur, dana yang terbatas, tidak terbiasa menulis dalam arti menulis karya ilmiah, kurang terbiasa dengan sistem kerja terjadwal dengan pengaturan waktu sedemikian ketat dan masalah dengan dosen pembimbing skripsi. Gejala stress yang banyak ditunjukkan oleh mahasiswa antara lain gangguan tidur seperti kesulitan tidur, sering terlihat cemas, mudah marah, dan ada beberapa mahasiswa yang menunjukkan gejala gangguan daya ingat yang ditunjukkan dengan seringnya mahasiswa lupa pada janji bimbingan dengan dosen pembimbing skripsi.

Mahasiswa mengalami stress disebabkan karena ketidakpastian dan gangguan dalam proses belajarnya. Mahasiswa harus menghentikan atau menunda penelitian (Zhai, Y., \& Du, 2020). Hambatan-hambatan dalam menuntaskan tugas skripsinya menimbulkan kecemasan pada diri mahasiswa. Kecemasan adalah keadaan takut berlebihan sebagai akibat dari adanya konflik pada kehidupan seseorang atau biasanya muncul saat seseorang dituntut untuk beradaptasi dengan perubahan situasi yang terjadi dalam hidupnya (Rau, M. J., Rahman, A. et al., 2017). Kecemasan tidak hanya bergantung pada faktor individu, tetapi juga dipengaruhi oleh sumber atau rangsangan yang membangkitkan kecemasan (Jeniu, E., Widodo, D. \& widiani, 2017)

Sebagian besar mahasiswa menghadapi kecemasan dalam menyusun proposal skripsi pada kategori sedang yaitu sebanyak 41,1\% (Kristianto, P. H., Pm, S., 2014). Sebanyak sembilan mahasiswa menyatakan cemas dalam menyusun skripsi. Penyebab cemas adalah terkait proses bimbingan, ketidakpercayaan diri, khawatir akan penelitian yang sulit, dan tuntutan dari orang tua. Gejala kecemasan yang dialami antara lain adalah sakit kepala, susah tidur, jantung berdebar-debar, mual, dan juga perubahan mood. Hal akan berakibat pada tertundanya bimbingan dan pengerjaan skripsi serta mundurnya target kelulusan (Listanto, 2015)

Salah satu cara untuk menyeimbangkan antara beban yang berat dan hasil yang maksimal adalah dengan memupuk rasa percaya pada kemampuan diri, sehingga akan muncul motivasi dan semangat untuk menyelesaikan tugas tepat waktu. Efikasi diri adalah keyakinan individu dalam memperkirakan kemampuannya dalam melaksanakan suatu tugas untuk mencapai hasil tertentu. (Rustika, 2016), efikasi diri yang tinggi akan memberikan dampak yang positif bagi seseorang. Efikasi diri yang tinggi akan menuntun individu untuk menghadapi tuntutan tugas yang ada (Shofiah, V., 2014)

Efikasi diri hendaknya dimiliki oleh setiap individu. Keyakinan individu akan kemampuan yang dimilikinya akan sangat berpengaruh terhadap proses keberhasilan dalam menggapai apa yang dicita-citakan. Keyakinan tersebut mampu memberikan dorongan untuk menghasilkan sebuah produk keahlian diri. Yang artinya efikasi yang tinggi seorang individu mampu memunculkan semangat untuk terus menjadikan seorang individu tersebut menjadi ahli dibidangnya. Ini sesuai dengan pendapat (Suseno, 2012) efikasi diri adalah keyakinan individu atas kemampuan diri untuk mengatur dan melaksanakan serangkaian tindakan yang diperlukan untuk menghasilkan suatu hal. Individu yang yakin atas kemampuan dirinya mampu menyusun strategi dan segala tindakannya akan mengarah kepada pencapaian tujuan.

Schunk (2012) mengatakan bahwa efikasi diri sebagai keyakinan individu terhadap kemampuan untuk berhasil menyelesaikan tugas-tugas pada tingkatan tertentu. Menurut (Alwisol., 2009) efikasi adalah penilaian diri, dilihat dari tindakan pelajar yang baik atau buruk, tepat atau salah, bisa atau tidak bisa mengerjakan sesuai dengan yang telah ditentukan. Alwisol juga menambahkan bahwa cara individu berperilaku dalam situasi tertentu bergantung pada hubungan antara lingkungan dengan kondisi kognitif, khususnya pada faktor kognitif yang berkaitan dengan keyakinannya bahwa dirinya mampu atau tidak mampu memunculkan perilaku yang sesuai dengan harapan, keyakinan ini dikenal dengan istilah efikasi diri. Efikasi diri seorang mahasiswa berkaitan dengan bagaimana mahasiswa mampu menyelesaikan skripsinya dengan baik dan tepat waktu. 
Fenomena yang terjadi pada mahasiswa IAIS Abdullah semester akhir tahun 2021 teridentifikasi masih banyak mahasiswa yang tidak yakin akan kemampuan dirinya sendiri. Sebagai contoh adanya sikap mengeluh ketika dosen memberikan revisi yang berulang pada tugas akhirnya. Dan hal ini mengakibatkan lemahnya semangat mahasiswa dalam menyelesaikan tugas akhir.

Penelitian ini dilakukan untuk mengetahui adanya korelasi antara efikasi diri terhadap kemampuan menulis skripsi mahasiswa Institut Agama Islam Abdullah Said Batam program studi Bimbingan Konseling Islami tahun 2021. Penelitian ini selaras dengan penelitian yang dilakukan oleh (Niken Saraswati, 2021) dengan hasil penelitian menunjukkan bahwa ada hubungan negatif antara efikasi diri dan kecemasan menyusun skripsi $(r=-0,445)$ yang mengindikasikan bahwa hubungan antara dua variabel cukup kuat.

\section{METODE PENELITIAN}

Penelitian ini menggunakan pendekatan kuantitatif dengan metode korelasional. Analisa data yang digunakan dalam penelitian ini adalah uji korelasi pearson. Penyebaran kuesioner dilakukan secara daring melalui aplikasi google form. Subjek dalam penelitian ini adalah mahasiswa Prodi Bimbingan dan Konseling Islam Institut Agama Islam Abdullah Said Batam Tahun 2021. Semua pernyataan dalam kuesioner disediakan empat alternatif jawaban dengan menggunakan skala Likert yaitu dari gradasi tertinggi sampai terendah yaitu sangat sesuai (SS), sesuai (S), tidak sesuai (TS), dan sangat tidak sesuai (STS). Rumus yang digunakan adalah rumus korelasi Pearson product moment dengan menggunakan topik-topik IBM SPSS Statistics Versi 20. Rumus korelasi Pearson product moment adalah sebagai berikut:

rxy $=$

$$
\frac{n \sum X Y-\sum X(\mathbb{E} Y)}{\left(N \sum X^{2}-\left(\sum X^{2}\right)\left(N \sum Y^{2}-\sum Y^{2}\right.\right.}
$$

Keterangan:

rxy : Koefisien korelasi

$\Sigma \mathrm{x}$ : Jumlah skor item /pertanyaan

$\Sigma$ y : Jumlah skor total (item)/total pertanyaan

$\Sigma x y:$ Jumlah hasil kali skor $\mathrm{x}$ dan skor y berpasangan

Analisis regresi dan uji hipotesis penelitian digunakan untuk melihat kontribusi sebagai prediktif sumbangan kesiapan mahasiswa maka peneliti juga melakukan uji normalitas data untuk melihat apakah data terdistribusi normal, uji linearitas data sebagai syarat untuk uji regresi dan hipotesis.

\section{HASIL DAN PEMBAHASAN}

\section{Hasil}

Pada penelitian didapat hasil bahwa efikasi diri mahasiswa sukup bagus sesuai dengan data pada tabel dibawah ini

Tabel 1. Kategorisasi Efikasi Diri Mahasiswa dalam menyusun skripsi pada Prodi Bimbingan Konseling IAIS Abdullah Said Batam

\begin{tabular}{|c|c|c|c|}
\hline Kategori & Interval & Frekuensi & Persentase \\
\hline $\begin{array}{c}\text { Sangat } \\
\text { Tinggi }\end{array}$ & $\geq 214,5$ & 28 & $71 \%$ \\
\hline Tinggi & $\begin{array}{r}181,5- \\
214,5\end{array}$ & 6 & $24 \%$ \\
\hline Sedang & $\begin{array}{r}148,5,5- \\
181,5\end{array}$ & 2 & $5 \%$ \\
\hline Rendah & $\begin{array}{r}115,5- \\
148,5\end{array}$ & 0 & $0 \%$ \\
\hline Sangat & $\leq 115,5$ & 0 & $0 \%$ \\
\hline
\end{tabular}




\begin{tabular}{|l|l|l|l|}
\hline Rendah & & \\
\hline Jumlah & 36 & $100 \%$ \\
\hline
\end{tabular}

Tabel 2. Uji Korelasi Pearson Product Moment Efikasi

Diri terhadap Kemampuan Menulis Skripsi Mahasiswa

IAIS Abdullah Said Tingkat Akhir Tahun 2021

\begin{tabular}{|ll|r|r|}
\hline & Pearson & \multicolumn{1}{c|}{$\begin{array}{c}\text { Efikasi } \\
\text { Diri }\end{array}$} & $\begin{array}{c}\text { Kemampuan } \\
\text { Menulis } \\
\text { Skripsi }\end{array}$ \\
\hline Efikasi Diri & Correlation & 1 & $.834^{* *}$ \\
& Sig. (2-tailed) & & .000 \\
& N & 36 & 36 \\
Kemampua & Cearson & $.834^{* *}$ & 1 \\
n Menulis & Sig. (2-tailed) & .000 & 36 \\
Skripsi & N & 36 & \\
\hline
\end{tabular}

**. Correlation is significant at the 0.01 level (2-tailed).

\section{Pembahasan}

Berdasarkan pemaparan hasil penelitian tersebut, pada tabel 1 dinyatakan bahwa sebagian besar mahasiswa penyusun skripsi Prodi Bimbingan dan Konseling Institut Agama Islam Abdullah Said Batam Tahun 2021 memiliki efikasi diri yang sangat tinggi, sebagian kecil memiliki efikasi diri tinggi dan sedang serta tidak terdapat mahasiswa yang memiliki efikasi diri rendah dan sangat rendah. Nilai pearson korelasi bernilai - 0 ,, arah hubungan kedua variabel tidak searah, jika efikasi diri meningkat maka kemampuan skripsi akan menurun dan sebaliknya Maka hubungan yang sangat kuat sesuai dengan standar hubungan nilai korelasi. Dari penelitian ini terdapat adanya korelasi yang kuat antara efikasi diri dan kemampuan menyelesaikan skripsi dengan nilai koefisien korelasi sebesar $-0,834$

Dalam penelitian ini terdapat hubungan yang cukup kuat antara efikasi diri dan kecemasan. Hasil penelitian ini didukung oleh penelitian yang disusun oleh (Alfaiz, Zulfikar, 2017) yang menunjukkan hasil adanya hubungan antara efikasi diri dengan kesiapan mahasiswa menyelesaikan tugas akhir. Diperoleh efikasi diri lebih memiliki kontribusi/prediktif terhadap kesiapan diri mahasiswa dalam karir dan tugas yaitu: nilai koefisien regresi 0,175 ; nilai t hitung 3,339; dan sig. 0,010 dibandingkan konsep diri nilai koefisien regresinya 0,074 ; nilai t hitung 1,133; dan sig. 0,258 .

Bandura (1997) menjelaskan that successful execution of task is best served by reasonably accurate efficacy appraisal; furthermore, overestimated efficacy judgment may serve to increase one's effort and persistence. Suksesnya individu dalam melaksanakan suatu performa tugas dalam praktik dan persepsinya maka individu itu semakin siap dan merasa yakin dengan karirnya sebagai calon konselor.

Efikasi diri merupakan persepsi individu mengenai seberapa baik individu tersebut dapat menyelesaikan suatu tugas atau masalah yang dihadapi (Safitri, D. P., \& Masykur, 2017). Individu yang tidak menganggap diri mereka kompeten kehilangan motivasi untuk menyelesaikan tugas-tugas sulit dan fokus pada kemungkinan kegagalan yang dapat terjadi (AL-Baddareen, G., Ghaith, S., \& Akour, 2015). Seseorang dengan efikasi diri rendah

Seseorang dengan efikasi diri yang tinggi akan mempunyai semangat untuk melanjutkan tulisannya meskipun dihadapkan pada berbagai tantangan, serta mempunyai keinginan yang tinggi untuk mencapai tujuan/target yang telah ditetapkan (AL-Baddareen, G., Ghaith, S., \& Akour, 2015). Mencapai keberhasilan akan memberi dampak efikasi yang berbeda-beda, tergantung proses pencapaiannya: (1) semakin sulit tugasnya, keberhasilan akan 
membuat efikasi semakin tinggi; (2) kerja sendiri, lebih meningkatkan efikasi dibanding kerja kelompok, dibantu orang lain; (3) kegagalan menurunkan efikasi, kalau orang merasa sudah berusaha sebaik mungkin; (4) kegagalan dalam suasana emosional / stress, dampaknya tidak seburuk kalau kondisinya normal; (5) kegagalan sesudah orang memiliki keyakinan efikasi yang kuat, dampaknya tidak seburuk kalau kegagalan itu terjadi pada orang yang keyakinan efikasinya belum kuat; dan (6) orang yang biasa berhasil, sesekali gagal tidak mempengaruhi efikasi (Alfaiz, Zulfikar, 2017). Seseorang dengan efikasi diri yang tinggi mempunyai pandangan untuk sukses dan yakin akan kemampuan yang dimiliki (Shofiah, V., 2014)

Tingkat tinggi rendahnya efikasi diri yang dimiliki individu, tentunya dipengaruhi oleh aspek-aspek efikasi diri. Menurut Bandura (Suseno, 2012) efikasi diri individu dipengaruhi oleh tiga aspek, yaitu; tingkat kesulitan tugas (magnitude), luas bidang perilaku (generality), dan kemantapan keyakinan (strength).

Bandura (Alwisol., 2009) mengungkapkan bahwa lingkungan dan tingkah laku juga menjadi salah satu faktor yang mempengaruhi efikasi diri seseorang dalam melakukan suatu hal. Misalnya mahasiswa tetap mengikuti bimbingan skripsi meskipun hujan karena yakin akan mendapatkan pemahaman baru tentang skripsi atau mahasiswa tetap mengerjakan skripsi meskipun melihat teman-temannya menunda-nunda mengerjakan skripsi. Ketika mahasiswa mampu menyelesaikan revisi dengan baik dan tekun meskipun dalam keadaan yang tidak memungkinkan maka mahasiswa tersebut memiliki efikasi diri yang tinggi.

Suksesnya individu dalam melaksanakan suatu performa tugas dalam praktik dan persepsinya maka individu itu semakin siap dan merasa yakin dengan karirnya sebagai calon konselor. Bandura (1997) menjelaskan that successful execution of task is best served by reasonably accurate efficacy appraisal; furthermore, overestimated efficacy judgment may serve to increase one's effort and persistence.

\section{KESIMPULAN}

Berdasarkan pemaparan hasil penelitian tersebut, dinyatakan bahwa sebagian besar mahasiswa penyusun skripsi Prodi Bimbingan dan Konseling Institut Agama Islam Abdullah Said Batam Tahun 2021 memiliki efikasi diri yang sangat tinggi, sebagian kecil memiliki efikasi diri tinggi dan sedang serta tidak terdapat mahasiswa yang memiliki efikasi diri rendah dan sangat rendah. Semakin tinggi efikasi diri seorang mahasiswa maka akan semakin terarah dan terasah kemampuan mahasiswa dalam menyelesaikan penyusunan skripsi.

Pendidikan tinggi merupakan wadah untuk mempersiapkan insan yang berakhlakul karimah, mempunyai keyakinan diri dan keahlian di bidangnya. Mampu mengaplikasikan dirinya di masyarakat sesuai dengan bidang ilmu yang diambilnya

Untuk mampu mengembangkan kemampuan diri secara optimal termasuk didalamnya penyusunan tugas akhir, mahasiswa hendaknya diberi ruang yang cukup. Pemberian tanggungjawab , dorongan positif baik lisan maupun perbuatan perlu terus diberikan. Dalam proses kognitif manusia di lingkungannya, pendidikan merupakan lembaga untuk membentuk sikap dan tindakan yang sesuai dengan norma-norma yang ada. Sehingga efikasi diri menjadi atribut bimbingan konseling yang perlu dibentuk bukan hanya dalam kesiapan karir namun untuk pembentukan karakter mulia seorang mahasiswa.

\section{DAFTAR PUSTAKA}

Akhadiah, Sabarti, dkk. (2012). Pembinaan Kemampuan Menulis Bahasa Indonesia. Jakarta, Erlangga.

AL-Baddareen, G., Ghaith, S., \& Akour, M. (2015). Self-efficacy, achievement goals, and metacognition as predicators of academic motivation. Procedia-S, doi: 10.1016/j.sbspro.2015.04.345.

Alfaiz, Zulfikar, D. Y. (2017). Efikasi Diri sebagai Faktor Prediksi Kesiapan Mahasiswa dalam Mengerjakan Tugas Kuliah. STKIP PGRI, Ilmu Pendidikan, Volume 2 Nomor 2,

Alwisol. (2009). Psikologi Kepribadian edisi revisi. Malang : UMM Press. 


\section{STRATEGY : Jurnal Inovasi Strategi dan Model Pembelajaran \\ Vol 1. No 2. Oktober Tahun 2021 e-ISSN : 2798-5466 P-ISSN : 2798-5725}

Ariani, Y. (2011). Hubungan antara motivasi dengan efikasi diri pasien dm tipe 2 dalam konteks asuhan keperawatan di RSUP. H. Adam Malik Medan.

Bacanli, F. (2016). Career decision-making difficulties of Turkish adolescents. International Journal for Educational and Vocational Guidance. 16(2), 233, https://doi.org/10.1007/s10775-015-9304-8.

Bandura, A. (1997). Self-Efficacy: The exercise of control. New York.

Danim, S. (1997). Metode Penelitian untuk Ilmu-ilmu Perilaku. Jakarta : Bumi Aksara.

Hurlock, E. B. (. (2011). Psikologi Perkembangan: Suatu Pendekatan Sepanjang Rentang Kehidupan. Erlangga.

Jeanne Ellis Ormrod. (2019). Psikologi Pendidikan Membantu Siswa Tumbuh Dan Berkembang. Jilid 2 Ed.

Jeniu, E., Widodo, D. \& widiani, E. (2017). Hubungan Pengetahuan Tentang Autistik dengan Tingkat Kecemasan Orang Tua yang Memiliki Anak Autistik di Sekolah Luar Biasa Bhakti Luhur Malang. Nursing Ne.

Kristianto, P. H., Pm, S., \& S. (2014). Hubungan antara kepercayaan diri dengan kecemasan. Listanto, W. dan I. P. K. D. (2015). Kecemasan Pada Mahasiswa Angkatan 2010 Yang Mengerjakan Tugas Akhir Program Studi Pendidikan Dokter Fkik Untad. Medika Tad, Jurnal Ilmiah Kedokteran, Vol. 2, No.1,

Niken Saraswati, dkk. (2021). Hubungan Efikasi Diri dengan Kecemasan Menyusun Skripsi pada Mahasiswa Keperawatan. Journal of. https://ejournal2.undip.ac.id/index.php/hnhs\%0ANiken Saraswati, dkk., Peningkatan Efikasi Diri Mahasiswa... 1\%0A

Persadha, K., A., D. (2016). Studi Kompetensi Kemampuan Menulis Di Kalangan Mahasiswa. Jurnal Pendidikan.

Rau, M. J., Rahman, A., \& R., G. RRau, M. J., Rahman, A., \& R., \& R, G. (2017). Faktor risiko kejadian gangguan ansietas di Rumah Sakit Umum Daerah Ampana Kota Kabupaten Tojo Una-Una Tahun 2016. Jurnal Pre.

Rustika, I. M. (2016). Efikasi diri: Tinjauan Teori Albert Bandura. Buletin Ps, doi: 10.22146/bpsi.11945.

Safitri, D. P., \& Masykur, A. M. (2017). Kejuaraan nasional pada atlet tenis Lapangan Pelti Semarang. Jurnal Emp.

Schunk, D. H. (2012). Learning Theories: An Educational Perspectives, 6th Edition. New York : Pearson Education Inc.

Shofiah, V., \& R. (2014). Self-efficacy dan self-regulation sebagai unsur penting dalam pendidikan karakter (Aplikasi pembelajaran Mata Kuliah Akhlak Tasawuf). Jurnal Pen.

Suseno, M. N. (2012). Pengaruh Pelatihan Komunikasi Interpersonal Terhadap Efikasi Diri Sebagai Pelatih Pada Mahasiswa. Jakarta Pusat : Kementerian Agama Republik Indonesia.

Zhai, Y., \& Du, X. (2020). Addressing collegiate mental health amid COVID- 19 pandemic. Psychiatry, doi: 10.1016/j.psychres.2020.113003. 